\title{
PRINCIPLES OF DEVELOPMENT AND IMPLEMENTATION OF THE PROGRAM OF INCREASING THE COMPETITIVENESS OF THE AMALGAMATED HROMADA OF THE REGION
}

\section{Solomiia Kloba ${ }^{1}$}

DOI: https://doi.org/10.30525/978-9934-26-076-6-28

Amalgamated hromada development programs are part of the approved development strategies of the respective Amalgamated hromada. Thus, the program cannot cover a more extended period than defined in the system and more petite than current development plans and budgets. Accordingly, development programs, including programs to increase competitiveness, can be developed for 2 to 3 years $[1 ; 2]$.

In our opinion, this is the optimal ratio because, after the end of the period for which the program is developed, it is possible to form a new program within the experience and existing strategy and within the term of office of elected Amalgamated hromada leaders.

At the initial stage of creating a program to increase the competitiveness of Amalgamated hromada, it is appropriate to justify an objective and accurate definition of the purpose and goals of this document. To do it is necessary to involve residents and the public of a particular Amalgamated hromada and analyze the existing development programs in the region, including Amalgamated hromada competitors.

To achieve the highest level of public involvement to identify potential and actual problems about which the authorities do not have sufficient information, Amalgamated hromada can use various tools, which is carried out in the legal field of Ukraine (Figure 1).

It should be noted that the accumulated information from citizens' appeals, electronic petitions, etc., needs to be analyzed and systematized. It can form the basis of the Amalgamated hromada Competitiveness Program, but only after systematization and analysis considering the statistical and economic information available to the Amalgamated hromada staff.

The goals and objectives must be based on the prerequisites for increasing the competitiveness of Amalgamated hromada (Figure 2).

\footnotetext{
${ }^{1}$ State Institution «Institute of Regional Research named after M.I. Dolishniy» of National Academy of Sciences of Ukraine», Ukraine
} 


\begin{tabular}{|c|c|c|}
\hline Tools for public participation \\
\hline general meeting of citizens \\
\hline public examination
\end{tabular}

\section{Figure 1. Tools for public involvement in Amalgamated hromada activities}

Source: developed by the author

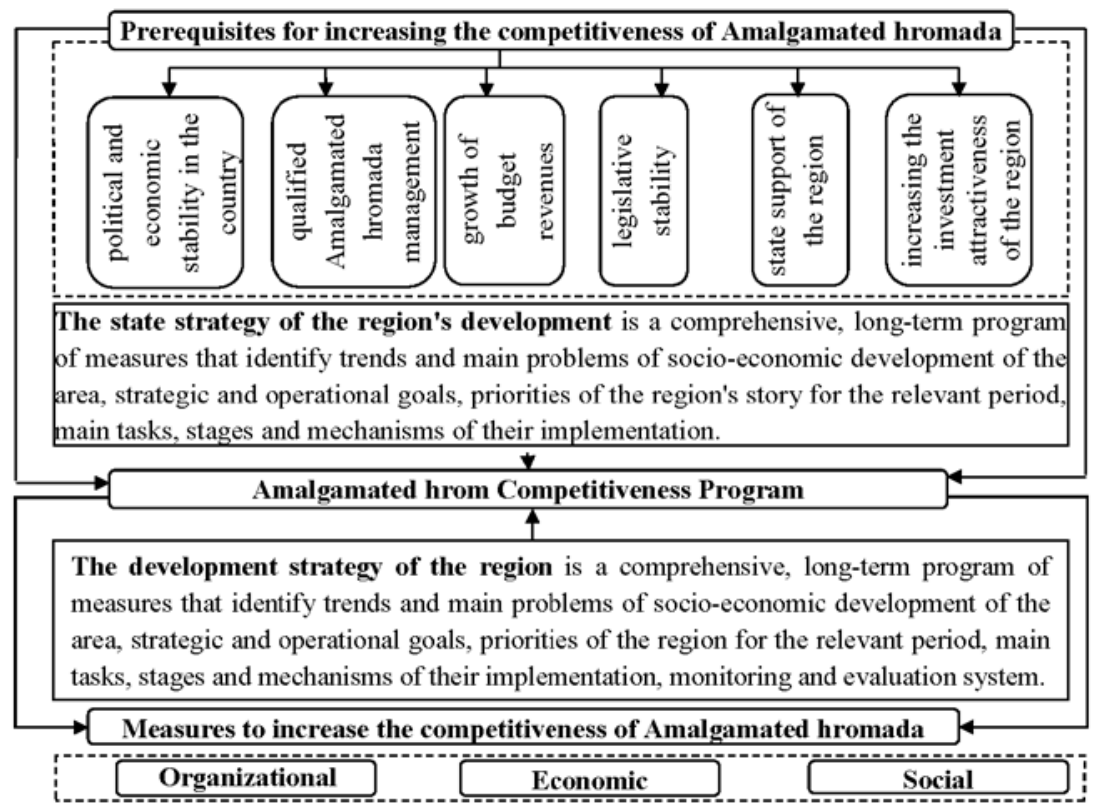

Figure 2. Prerequisites for increasing the competitiveness of Amalgamated hromada

Source: developed by the author

These prerequisites are external factors that determine the adequacy and objectivity, completeness and effectiveness of the existing Competitiveness 
Program (from now on - the Program). For example, the political situation in a country, the variability of legislation, or the state's willingness to support communities directly affect the goals and objectives of the Program.

Existence of the state strategy of development of regions - defines priorities and directions of the priority financing from the State budget of Ukraine, and potential measures of competitiveness of Amalgamated hromada follow from features of the legislative and political field of Ukraine. Implementation of the Program, taking into account the specified legislative lot, should be based on some principles:

1. Economic feasibility, as compliance with this principle allows reducing expenditures in weak areas.

2. Targeted use of funds, which will track the use of funds.

3. Efficiencies, and therefore the effects of financial investments, should not be adverse.

4. Planning - because both the participants of the Program and the governing bodies of Amalgamated hromada are interested in the clearest possible compliance with the terms and amounts of funding specified in the Program.

5. Parity - among the submitted projects are selected only those that will bring maximum competitive advantage to the community.

6. Innovation orientation - definition of separate directions and tasks of the Program for acceptance and introduction of new technological decisions in certain kinds of economic activity, taking into account the innovative potential of the region.

These principles will allow to carry out the necessary stages of implementation of the Program with the minimum threats of its violation and the full observance of terms of execution of the projects specified in the program.

The formed goals can be put forward for public discussion or a local referendum. Goals can be:

- In the educational sphere: introduction of modern information technologies in the educational process of the state standard of primary education; fulfilment of tasks of social protection of orphans and children deprived of parental care; promoting the provision of village council schools with a pedagogical staff of appropriate professional training; meeting the needs of the community in preschool institutions; organization of proper conditions to ensure the learning process, etc.

- In the field of agriculture: ensuring the protection and rational use of land; ensuring equal access of agricultural producers, regardless of the form of management, to state and regional programs to support the development of the agro-industrial complex and the social sphere, financed from the State and 
local budgets; growth of gross agricultural output; increasing crop yields, increasing the level of wages of agricultural workers, etc.

- In the field of economic development: ensuring the completeness of the payment of rent for land plots of state and communal property in accordance with the concluded land lease agreements; improving the management of private property shares of peasants, by leasing and concessioning them, corporatization, corporatization or sale through auctions; ensuring the timeliness and completeness of payment of taxes and fees (mandatory payments) to the consolidated, state and local budgets; targeted, rational and economical spending of budget funds; ensuring priority and socially oriented expenditures; providing timely and complete settlements of the objects of the budget sphere of the village for the consumed energy resources; strengthening of preliminary and current control over the targeted and effective use of budget funds, introduction of effective measures to prevent violations and timely elimination of identified violations; increasing the efficiency of implementation of local, regional, state target programs for rural development.

The goal can be the quintessence of dreams and increase the welfare and quality of life of the Amalgamated hromada population by providing positive structural changes in the economy, increasing the competitiveness of Amalgamated hromada, as a basis for balanced growth of standards and indicators of community economic development.

Having defined the goals and objectives of the program, it is necessary to proceed to the following stages of developing a program to increase the competitiveness of Amalgamated hromada in the region (Figure 3). Consistency of the program's goals with the approved Amalgamated hromada Development Strategy will reduce additional costs and optimize the ways of filling and using community funds.

Thus, achieving the Program's goals of using Amalgamated hromada competitive advantages will provide additional benefits not only to Amalgamated hromada management, but also to its residents through the release of additional resources that can be directed to the development of social infrastructure and attractiveness to potential residents, businesses and investors. increase in revenues to local budgets in terms of consumption budget. 


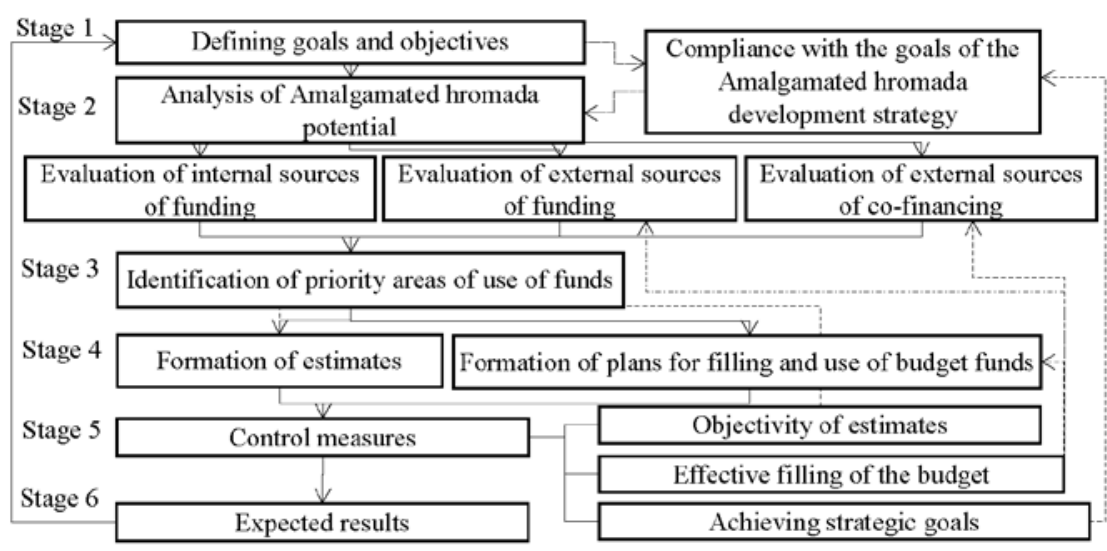

Figure 3. Algorithm for developing a program to increase the competitiveness of the Amalgamated hromada

Source: developed by the author

\section{References:}

1. Pro derzhavne proghnozuvannja ta rozroblennja proghram ekonomichnogho i socialjnogho rozvytku Ukrajiny: Zakon Ukrainy vid 02.12.2012 № 1602-III. Vidomosti Verkhovnoi Rady (VVR), 2012, № 25, st. 195. Available at: https://zakon.rada.gov.ua/laws/show/1602-14

2. Pro dobroviljne ob'jednannja terytorialjnykh ghromad: Zakon Ukrainy vid 05.02.2015 № 157-VIII. Vidomosti Verkhovnoi Rady (VVR), 2015, № 13, st. 91. Available at: https://zakon.rada.gov.ua/laws/show/157-viii 